\title{
LEVEL OF SPATIAL DIFFERENTIATION OF ANTHROPOGENIC IMPACT IN MAŁOPOLSKA
}

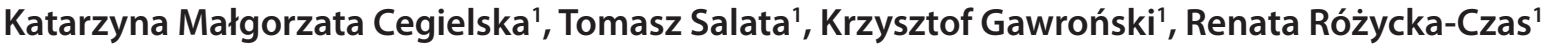 \\ Hugo Kollataj University of Agriculture in Krakow, Faculty of Environmental Engineering and Land Surveying, \\ Department of Spatial Management and Landscape Architecture, Mickiewicza 21, 31-120 Krakow, Poland, \\ e-mail: cegielska_katarzyna@wp.pl
}

Received: 2016.10 .14

Accepted: 2016.11.16 Published: 2017.01.01

\begin{abstract}
Detailed spatial analysis of area coverage was performed in the present paper, which allowed to determine numerous derivative parameters connected with human activity as well as natural processes. Data from Database of Topographic Objects in nominal scale 1:10 000 (in short: BDOT10k) in GML format were used as source materials and processing of the source data to object-relational form of SpatialLite database was performed. Methods of areas classification and valorization on the basis of land coverage diversity were used in the research after using modification of classes selection to BDOT10k. Borders of spatial objects had geo-referential precision to $3 \mathrm{~m}$ and were not subjected to generalization process. It provided possibility to achieve high degree of credibility of calculated parameters. Materials that concern ecological corridors were obtained from the General Directorate for Environmental Protection by means of WFS service. Geoprocessing methods and spatial connections in GIS heterogenic systems were used to perform analyses. The effects of all the conducted analyses allowed to identify problem fields where areas of ecological corridors became strongly anthropogenized. The results were presented as multilayered compositions and cartograms. The research area covered $15,200 \mathrm{~km}^{2}$ and ranged the territory of Małopolska province.
\end{abstract}

Keywords: land use parameters, GIS computing, spatial data quality, BDOT10k Topographic Geodatabase

\section{INTRODUCTION}

Landscape is created by expanded number of elements that join and influence each other. Changing one element affects the change of the other both in size and their mutual location. Recognition of these changes' directions as well as their dynamics is an element which reasonably supports space management [Drzewiecki 2008]. A term of land usage and coverage is often used in landscape surveys [Krajewski 2010]. It is crucial to distinguish between them. The land coverage is in a way of statistical value whereas the usage - a category of functional character which is connected with using the given area by a man (e.g. a land coverage - an arable land, a land usage - an area used agriculturally) [Kistowski 2003].
Significance of a clear line between these two terms is also confirmed by their distinction in the Ordinance of the Minister of Internal Affairs and Administration of 17 November 2011 on database of topographic objects and database of general geographic objects and also typical cartographic elaborations where issues of land coverage were addressed. Unit $5 \S 12.1$. of the attachment to the Ordinance says that representations of objects' every category are coherent land fragments that are uniform areas in regard to physiognomy. Land coverage complexes are defined as the most important situational surface elements of the area. Their distinction is performed on the basis of their appearance. On the contrary, usage complexes contain information about land exploitation. The Ordinance mentioned above states that the objects 
which belong to the land coverage category stay to each other in relation to the neighbourhood and cover all elaborated land in a permanent way.

There are many definitions of landscape [Pietrzak 2010, Pietrzak 2015], however, according to Kozak et al. [2014], its sense amounts to two main aspects: landscape treated as a harmonious whole that takes varied natural and anthropogenic elements into account [European Landscape Convention 2006] and landscape that composes comprehensive and diverse way of cooperation of environmental components which interact with each other. Landscape's term joins significantly with the aspect of landscape's coverage that is a key variable by means of which it is described [Kozak et al. 2014].

Anthropogenic transformations of landscape are construed as intensity of human impact on the environment - the influence strength of anthropogenic environment system on natural environment system. Complex dependencies exist between the mentioned systems that shape spatial structure of a given area, as a result of which mosaic of landscape units associations come into being that reflects mutual relations between them and determines the degree of landscape transformation (on the basis of its natural character) [Degórski 2009]. At present, spatial processes occur much quicker. It can also be observed that there are two strengthening tendencies with much extreme character. Development of urbanization, technology and transport influences increase of usage intensity and the way of land management. On the other hand, however, specific marginalization of land fragments can be observed as demonstrated by the occurrence of wasteland grounds without any function. Both processes lead to significant changes in landscape's structure causing disappearance of its traditional forms. Elements that did not exist so far and are changing its past character start to appear in their place [Jaworek 2012]. Trials of evaluating influence of human impact on natural environment join significantly with determining the rate of landscape transformation under the influence of anthropopression. Surveys in that range are carried out for a long time and concern many elements, such as evaluation of flora anthropization rate, naturalness level of landscape physiognomy or landscape dynamics [Degórski 2009].

The starting point for analyses was Krajewski's theorem [2011] which says that there are two elements - land shape and coverage - that af- fect landscape perception the most. The first factor was not subject to significant transformations on the tested area so it was not taken into consideration. As Kozak et al. [2014] say, a considerable number of surveys on landscape amount to the analysis of land coverage as the only variable [Jobin et al. 2003, Hladnik 2005]. Such attempts are mainly used in case of quantification of landscape spatial structure (horizontal one) in static terms. According to Solon's opinion [2002], spatial aspect that examines relations of arrangement of the analysed elements, liaison aspect that considers elements' mutual neighbourhood, form aspect which concerns elements' outside shape as well as generic-quantitative aspect that indicates quantitative share of every element in the whole system are taken into consideration in such a case. The performed surveys considered Małopolska anthropogenisation rate which was determined by means of data from the public Database of Topographic Objects in nominal scale 1:10000 (in short: BDOT10k) established by state administration organs which concern land coverage. Collected results were confronted with spatial range of ecological corridors located in Małopolska.

\section{THE AREA OF SURVEYS}

The surveys were performed in the territory of Małopolska province which covers the area of $15,108 \mathrm{~km}^{2}$ and consists of 21 districts [Yearbook] (Fig. 1).

In 2014, this area was inhabited by $3,368,000$ people which was $8.8 \%$ of the country's population (state for 31.12.2015) [Yearbook]. Within the decade (2001-2010), the number of inhabitants increased by $2.5 \%$, mainly in Wieliczka, Tarnow and Krakow districts, which was influenced by favourable dynamics of demographic phenomena such as positive migration balance and positive birth rate which according to the Yearbook from 2015 fluctuated at around 1.4 per 1000 people. As Development Strategy of Małopolska Province [2011] says, 44,000 people came to Małopolska in 2009 (twice as many as in the previous year) and, in accordance with the Yearbook, balance of migrations inside and abroad for permanent residence per 1,000 people in 2015 was 0.9 (the height of a factor for Poland -0.4). Małopolska is characterised with high density of population (on average 222 persons $/ \mathrm{km}^{2}$ with higher density in 


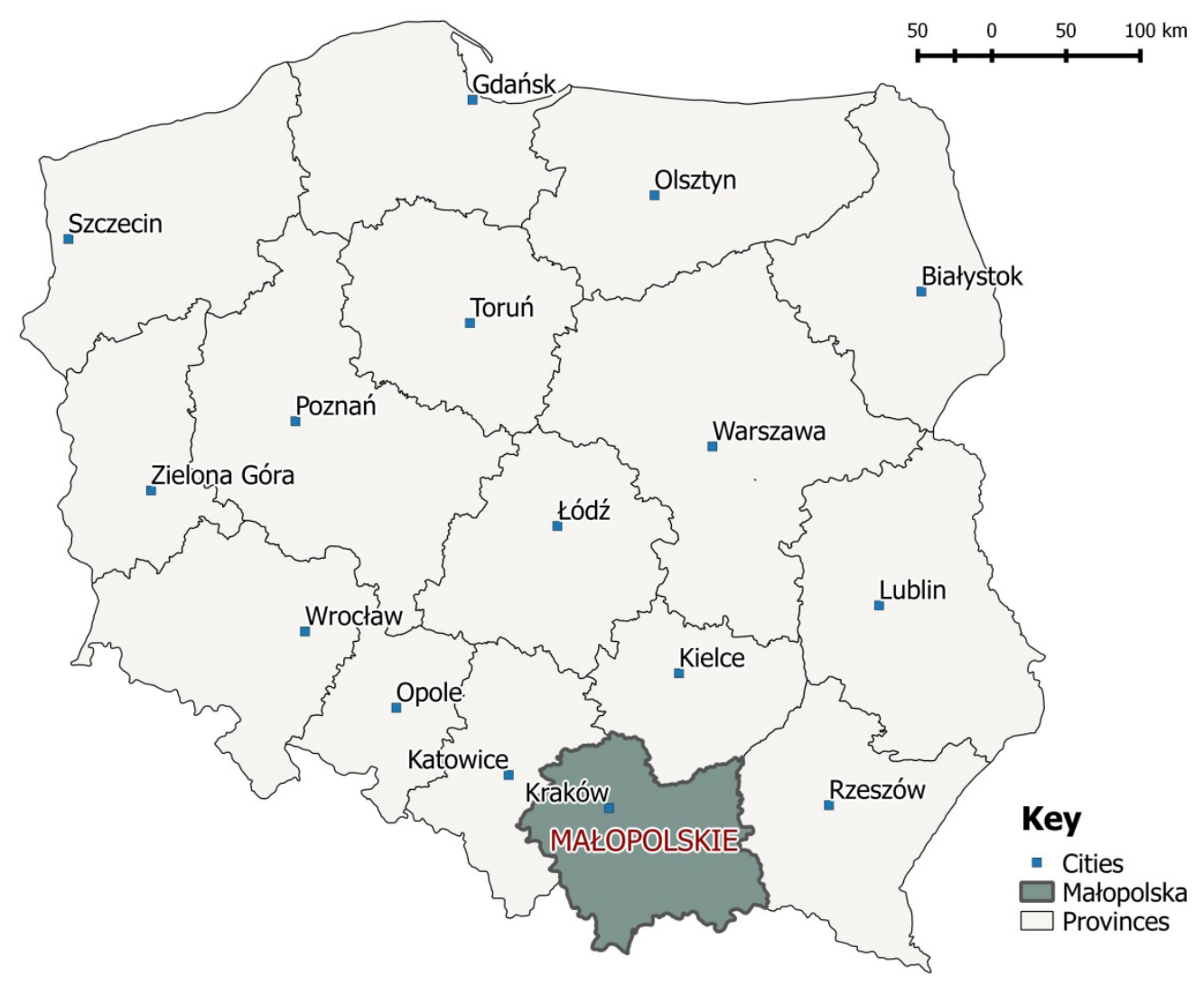

Figure 1. Research area

cities and lower - in the country with the height of the factor for Poland lower by 99 persons). Analyzing demographic prospects, it is worth noting that with a view to 2020 the number of people will be constantly raising [Strategy 2011].

Performing the analysis of region's investment attraction, it should be stated that Małopolska is described as an attractive place for locating investments. As the ranking of Research over Market Economy Institute (in Polish: Instytut Badań na Gospodarką Rynkową) says, the year 2010 was the time of growth of Małopolska position from the fifth to the fourth place among regions that are attractive for investments [Strategy 2011].

Taking the above development conditions and high residential attractiveness of Małopolska into consideration, it can be stated that this area is exposed to high anthropopression at natural ecosystems. As Environment Protection Strategic Programme [2014] quotes, Małopolska province is subject to anthropopression growth in forest and meadow ecosystems. It can cause irreversible changes in ecological ecosystems and that is why testing anthropopression strength and determining areas exposed to it makes a significant challenge.
Anthropopression that occurs in the province reflects in the values of areas occupied by builtup and urbanized lands and, above all, their gradual increase (Table 1). Housing and transport lands take the biggest areas of all categories. Over 10 years (2005-2015), total built-up and urbanized area increased by 1,548 ha. The biggest area growth is visible in case of the areas intended for housing (doubled value) which confirms residential attractiveness of the region.

Comparison of statistical data that come from Central Statistical Office (in Polish short: GUS) with the data collected within the performed analyses is impossible. In statistical elaboration, there is a lack of data concerning land coverage, only its usage is distinguished. Kistowski [2003] and Krajewki [2010] (among others) and the Ordinance of the Minister of Internal Affairs and Administration of 17 November 2011 itself pay attention that the same treatment of coverage and usage categories is incorrect. The second factor which arguments for inability to check a correlation between GUS data and the results of the present research is the fact that GUS data are record data that are in many cases out of date. 
Table 1. Changes in land usage of Małopolska province area

\begin{tabular}{|c|c|c|c|c|}
\hline \multirow[t]{2}{*}{ Specification } & 2005 & 2010 & 2015 & $\begin{array}{l}\text { Growth }(+) \text { or loss }(-) \\
\text { in relation to } 2014\end{array}$ \\
\hline & \multicolumn{4}{|c|}{ ha } \\
\hline Agricultural lands & 942,072 & 937,040 & 922,656 & $-1,684$ \\
\hline arable lands & 668,109 & 667,136 & 656,715 & $-1,594$ \\
\hline orchards & 34,145 & 31,094 & 28,237 & -148 \\
\hline permanent meadows & 100,410 & 98,917 & 98,001 & -96 \\
\hline permanent pastures & 94,279 & 93,337 & 92,945 & -101 \\
\hline built-up agricultural lands & 41,762 & 40,184 & 39,807 & 211 \\
\hline lands under ponds & 660 & 3,709 & 4,274 & 95 \\
\hline lands under ditches & 2,706 & 2,663 & 2,677 & -51 \\
\hline Forest lands wooded and shrubbed & 455,646 & 459,465 & 463,966 & 168 \\
\hline forests & 434,360 & 438,280 & 440,672 & 8 \\
\hline wooded and shrubbed lands & 21,286 & 21,185 & 23,294 & 160 \\
\hline Land under surface waters & 23,053 & 20,138 & 20,603 & -38 \\
\hline floating & 17,120 & 17,347 & 18,487 & 25 \\
\hline still & 5,932 & 2,791 & 2,116 & -63 \\
\hline Built-up and urbanized lands & 76,333 & 83,796 & 93,637 & 1,548 \\
\hline housing areas & 11,103 & 16,999 & 22,978 & 589 \\
\hline industrial areas & 6,574 & 7,258 & 7,747 & 94 \\
\hline the other built-up areas & 6,753 & 8,102 & 9,593 & 260 \\
\hline urbanised not built-up areas & 2,219 & 2,131 & 2,040 & 11 \\
\hline areas of recreation and rest & 3,301 & 3,146 & 3,321 & 51 \\
\hline transport areas & 45,272 & 45,068 & 46,860 & 551 \\
\hline roads & 40,344 & 40,164 & 41,880 & 527 \\
\hline railways & 4,436 & 4,374 & 4,444 & -14 \\
\hline other & 492 & 530 & 536 & 38 \\
\hline fossil uses & 1,111 & 1,092 & 1,098 & -8 \\
\hline Ecological uses & 566 & 573 & 636 & 79 \\
\hline Wastelands & 10,109 & 11,625 & 11,449 & -24 \\
\hline Various areas & 11,196 & 5,642 & 5,332 & -49 \\
\hline
\end{tabular}

Source: Own study on the basis of Statistical Office in Krakow elaboration (http://krakow.stat.gov.pl/ dane-o-wojewodztwie/wojewodztwo-918/rolnictwo-lesnictwo-srodowisko/)

\section{MATERIAL AND METHODS}

Assignation of the area of objects which are components of particular classes of land coverage was determined in a supplement to the Ordinance of the Minister of Internal Affairs and Administration of 17 November 2011 according to which:

- the smallest assigned area should not be less than $1,000 \mathrm{~m}^{2}$ (without considering special situations and in case of fragments of objects placed on the border of elaboration),

- minimal width of assigned area should be bigger than $125 \mathrm{~m}$ (except for special cases that concern transport areas and surface waters).

The Ordinance allows to assign areas smaller than indicated above. It takes place in a situation when the given area is a significant factor in terms of area illustration correctness. When the criterion of significance and one of minimal areas are not fulfilled the given fragment of coverage is included in an adjacent area. Assignation standards of areas with particular kinds of coverage were also used in CORINE Land Cover project.

The analyses within surveys concerning Małopolska rate of anthropogenisation were performed on the basis of areas classification and valorization proposed by professor Ivan Bičik et al. [2015]. In order to adapt this method to be used in Poland, its modification and adaptation to the state classification of topographical objects BDOT10k was performed (Table 2). The work consisted in calculating the factor of anthropogenic influence and graphic presentation of results. 
Table 2. Classification of BDOT10k objects (land cover) - anthropogenic influence

\begin{tabular}{|c|c|c|c|c|}
\hline \multirow{29}{*}{ 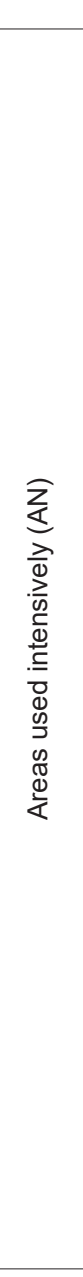 } & \multirow{2}{*}{$\begin{array}{c}\text { Usage } \\
\mathrm{AL}\end{array}$} & \multicolumn{2}{|c|}{ BDOT10k-code } & \multirow{2}{*}{$\begin{array}{l}\text { Object's name } \\
\text { cultivation on arable lands }\end{array}$} \\
\hline & & PTTR & 02 & \\
\hline & \multirow{17}{*}{ BA } & \multirow{5}{*}{ PTZB } & 01 & multi-family housing \\
\hline & & & 02 & single-family housing \\
\hline & & & 03 & industrial and store building \\
\hline & & & 04 & commercial and service building \\
\hline & & & 05 & remaining biulding \\
\hline & & \multirow{4}{*}{ PTKM } & 01 & area under road \\
\hline & & & 02 & area under railway \\
\hline & & & 03 & area under road and railway \\
\hline & & & 04 & area under airport road \\
\hline & & \multirow{2}{*}{ PTNZ } & 01 & area under technical appliances or constructions \\
\hline & & & 02 & industrial and store area \\
\hline & & PTPL & 01 & square \\
\hline & & \multirow{5}{*}{ PTUT } & 01 & allotment garden \\
\hline & & & 02 & plantation \\
\hline & & & 03 & orchard \\
\hline & & & 04 & forest tree nursery \\
\hline & & & 05 & ornamental and fruit plant nursery \\
\hline & \multirow{10}{*}{ RA } & PTLZ & 03 & forest cover \\
\hline & & PTRK & 02 & bushes \\
\hline & & \multirow{4}{*}{ PTGN } & 01 & scree, heap or debris \\
\hline & & & 02 & stony area \\
\hline & & & 03 & sandy or gravelly area \\
\hline & & & 04 & remaining not-used land \\
\hline & & \multirow{2}{*}{ PTWZ } & 01 & excavation \\
\hline & & & 02 & dumping ground \\
\hline & & \multirow{2}{*}{ PTSO } & 01 & area of urban wastes storage \\
\hline & & & 02 & area of industrial wastes storage \\
\hline \multirow{7}{*}{ 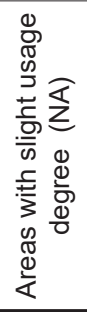 } & PG & PTTR & 01 & grassy plants \\
\hline & \multirow{3}{*}{ FA } & \multirow{2}{*}{ PTLZ } & 01 & forest \\
\hline & & & 02 & coppice \\
\hline & & PTRK & 01 & dwarf mountain pine \\
\hline & \multirow{3}{*}{ WA } & \multirow{3}{*}{ PTWP } & 01 & sea water \\
\hline & & & 02 & floating watera \\
\hline & & & 03 & still water \\
\hline
\end{tabular}

Source: Own study on the basis of BDOT10k classification and I. Bičik (2015)

Anthropogenic influence (by Bičik et al. 2015):

$$
\mathrm{CAI}=\frac{A L+B A+R A}{P G+F A+W A}
$$

where: $C A I$ - coefficient of anthropogenic influence

$L$ - arable land $[\%]$

$B A$ - built-up areas [\%]

$R A$ - remaining areas [\%]

$P G$ - permanent grassland, pastures [\%]

$F A$ - forest areas [\%]

$W A$ - water areas [\%]

The coefficient of anthropogenic influence consists of 6 main kinds of coverage and it is a ratio of the sum of percentile areas of lands char- acterised by considerable human impact (arable land, built-up areas, remaining areas) in relation to the sum of percentile areas of lands not burdened with anthropogenic pressure (permanent grassland, forest areas, water areas). Every main coverage category that was used is composed of matched with it particular kinds of coverage from BDOT10k classification, both at II and III level of accuracy which is the first stage of modification by Bičik's method.

Received results were confronted with spatial range that occurs in ecological corridors in Małopolska. The data was acquired within Geoservice led by the General Directorate for Environmental Protection by means of one of services 
created according to open standards of Open Geospatial Consortium (in accordance with the Directive 2007/2/WE of European Parliament of 14 March 2007 about infrastructure of spatial information in European Community and also notations of the Act of 4 March 2010 about infrastructure of spatial information) - the service of WFS downloading.

Analysing values' domains taken by CAI function, it was stated that the result value is mainly dependent on two coefficients: the sum of areas of anthropogenic lands $\mathrm{AN}=(\mathrm{AL}+\mathrm{BA}+\mathrm{RA})$ and natural ones $\mathrm{NA}=(\mathrm{PG}+\mathrm{FA}+\mathrm{WA})$. Mutual dependencies are almost symmetrical only in a narrow range of surface balance of constituted sums in the field of basic estimation (in Polish short: PPO). When in PPO all area classes add up to the whole then their quotient creates the function $y=1 / x$ (hyperbola) because in the finished value of total area PPO loss of area's part AN causes an increase of NA area and vice versa. So, it is for extreme case where values AN or NA move towards 0 . In the first case, CAI value comes to 0 in a nonlinear way, whereas in the second one, it goes to infinity but it causes dividing by zero 0 for $\mathrm{AN}=\mathrm{PPO}$. Also proportion of NA and AN values allocates in a nonlinear way far from the CAI force axis of symmetry. If the force of AN proportion is equal, for example to 50 , it means that $\mathrm{NA}=1 / 50$. CAI distribution depending on extreme values of AN and NA was presented in picture 2. A short-term solution of the case AN $=\mathrm{PPO}$ as well as NA $=0$ is to add 1 to the de- nominator in the formula for CAI but when PPO equal to $250,000 \mathrm{~m}^{2}$ is used, it implements constant error of 0.004 per mil. Considering that used technology of data obtaining guarantees standard error in the range of $1 \%$, such inaccuracy can be neglected. It is the next modification of the algorithm of Bičik et al. (2015) that adapts the results' domain to the linear scale.

For values of natural areas NA anthropogenic ones $\mathrm{AN}$, in case of regular completion of PPO area, CAI coefficient takes values close to 1 , values bigger than 1 (in the range from $1 \sim$ infinity) mean anthropogenized areas, whereas values smaller than 1 (in the range $1 \sim 0$ ) describe natural areas. Non-linearity (hyperbolicity of functions) is a flaw of CAI calculated in such a way. Modification of Bicik's method (2015) and calculating of AN percentile share in PPO causes that linear distribution of functions is obtained without losing the idea of CAI parameter. Moreover, the states that were not determined in $\mathrm{AN}$ values that come to 0 and to PPO do not occur and the domain of possible CAI values is comprised between 0 and 1.

A field of basic evaluation is the area with the side of $500 \times 500 \mathrm{~m}$ in square shape. The test area should be chosen properly to the character of the tested land. It is accepted for such a kind of surveys that the optimal shape is a square with dimensions $500 \times 500 \mathrm{~m}$ or $1 \times 1 \mathrm{~km}$ where the second one is preferably used in surveys for bigger regions. Too small PPO would cause increase of differences of CAI values between adjacent PPO,

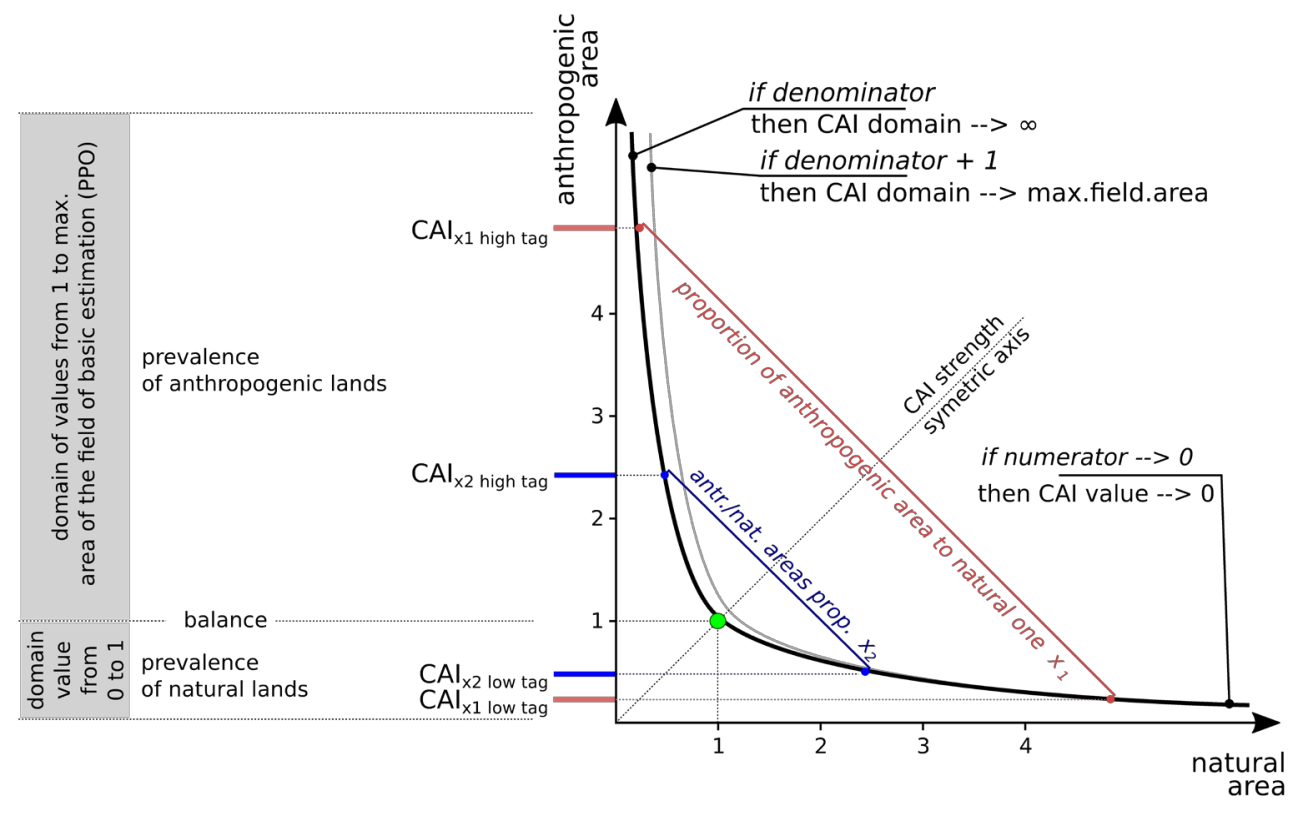

Figure 2. CAI variability for extreme NA and AN values 
whereas extension of PPO to bigger areas will be counterproductive: differences between adjacent test areas will be flattened and CAI values for areas standing out of the background but with a small territory will be generalized. Spatial dependencies of basic evaluation fields as well as objects of land coverage collected in BDOT10k database together with the background of classified value of CAI parameter were presented in Figure 3. Every PPO also contains borders of individual categories of land coverage.

Colour scheme of CAI parameter (Fig. 3) was chosen as follows:

- tones of green - PPO with predomination of natural areas,

- tones of yellow - balance,

- tones of red - PPO with predomination of anthropogenic areas.

\section{RESULTS AND DISCUSSION}

Spatial distribution of CAI parameter which can also be called areas anthropogenisation is interesting in itself. Considerable diversity for
Małopolska's southern part can be observed, whereas the strongly anthropogenized areas create a uniform territory in the north of the province. Detailed spatial distribution is presented in Figure 4.

Nevertheless, such parameters as CAI that stand for the degree of land transformation by human could serve to verify solutions with multicriteria character from the range of environment protection, spatial planning and identification of problem areas. Variability of land coverage classes and also types of usage are significant factors with share of which the surrounding landscape is formed and changes that are most often caused by anthropogenic activity can affect whole ecosystems [Wężyk et al. 2013]. Verifying ecological corridors course established by GDOŚ and the main function of areas through which they run such as anthropogenisation level expressed by CAI parameter values can be such example. Imposition of CAI layers and ecological corridors in Małopolska province is presented by Figure 5.

Identification of areas from two extreme CAI ranges with the area occupied by the ecological corridor was important for the above analysis. In

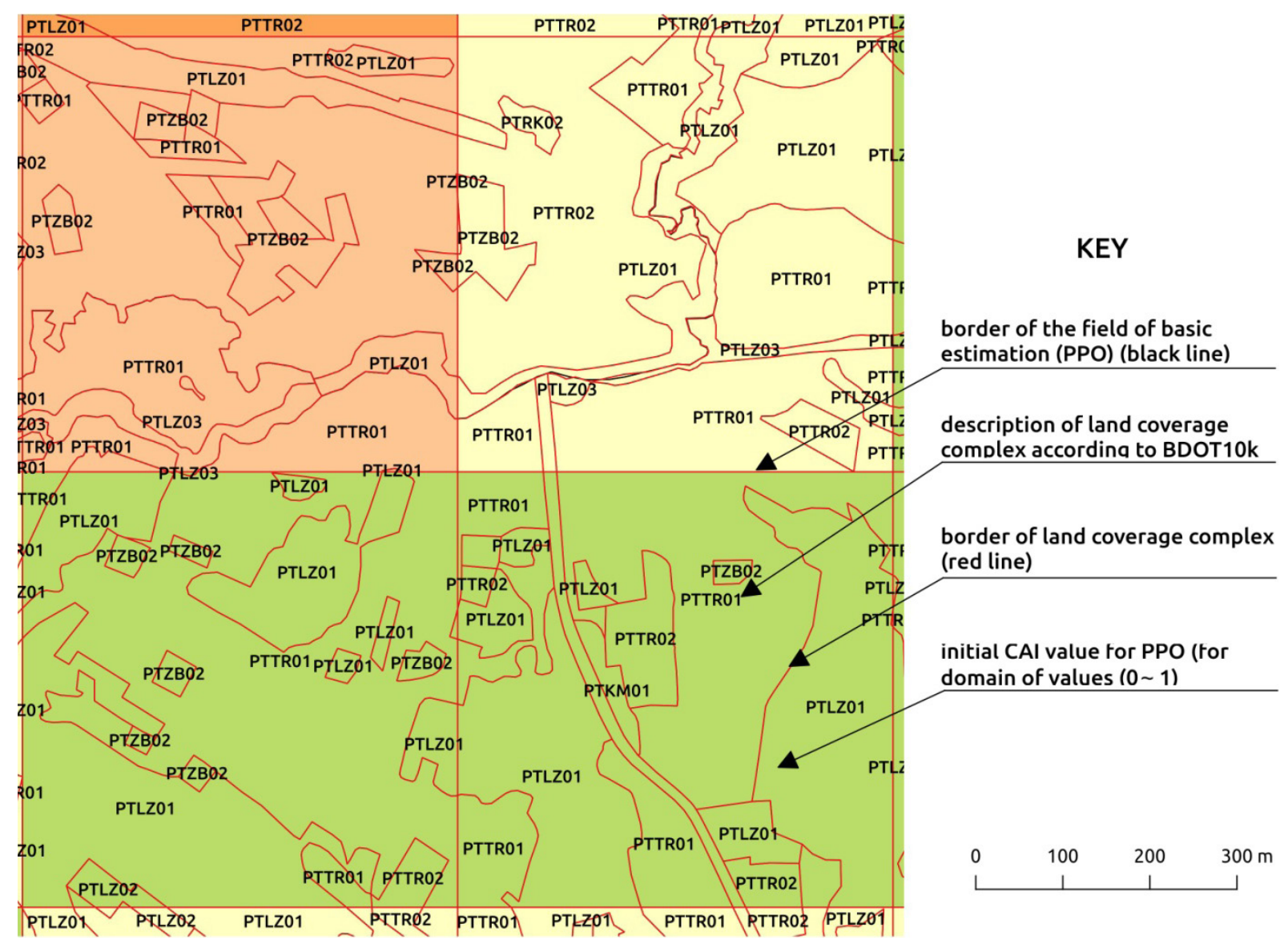

Figure 3. The PPO and the BDOT10k land coverage objects spatial distribution 


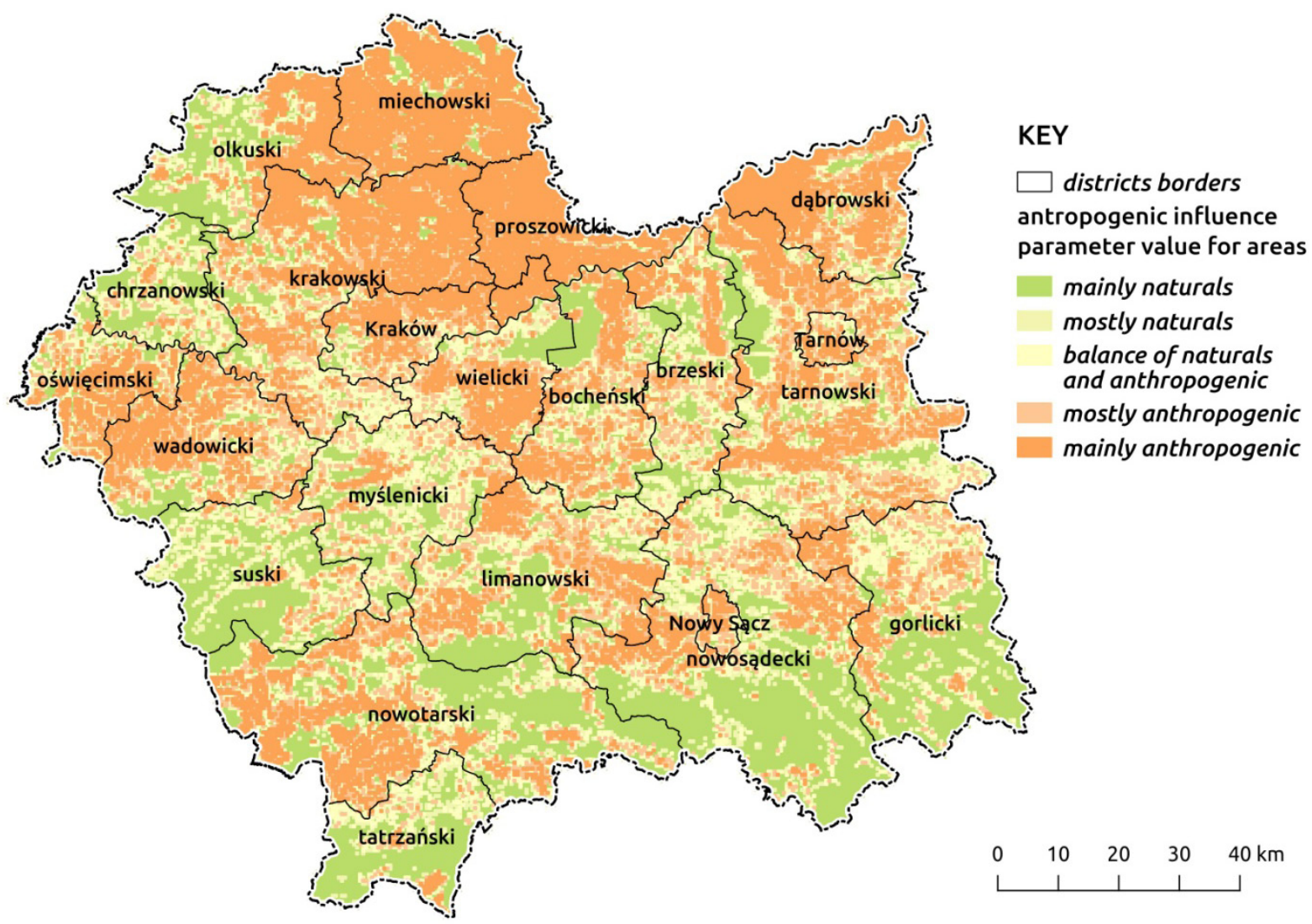

Figure 4. The CAI spatial distribution for the Małopolska province

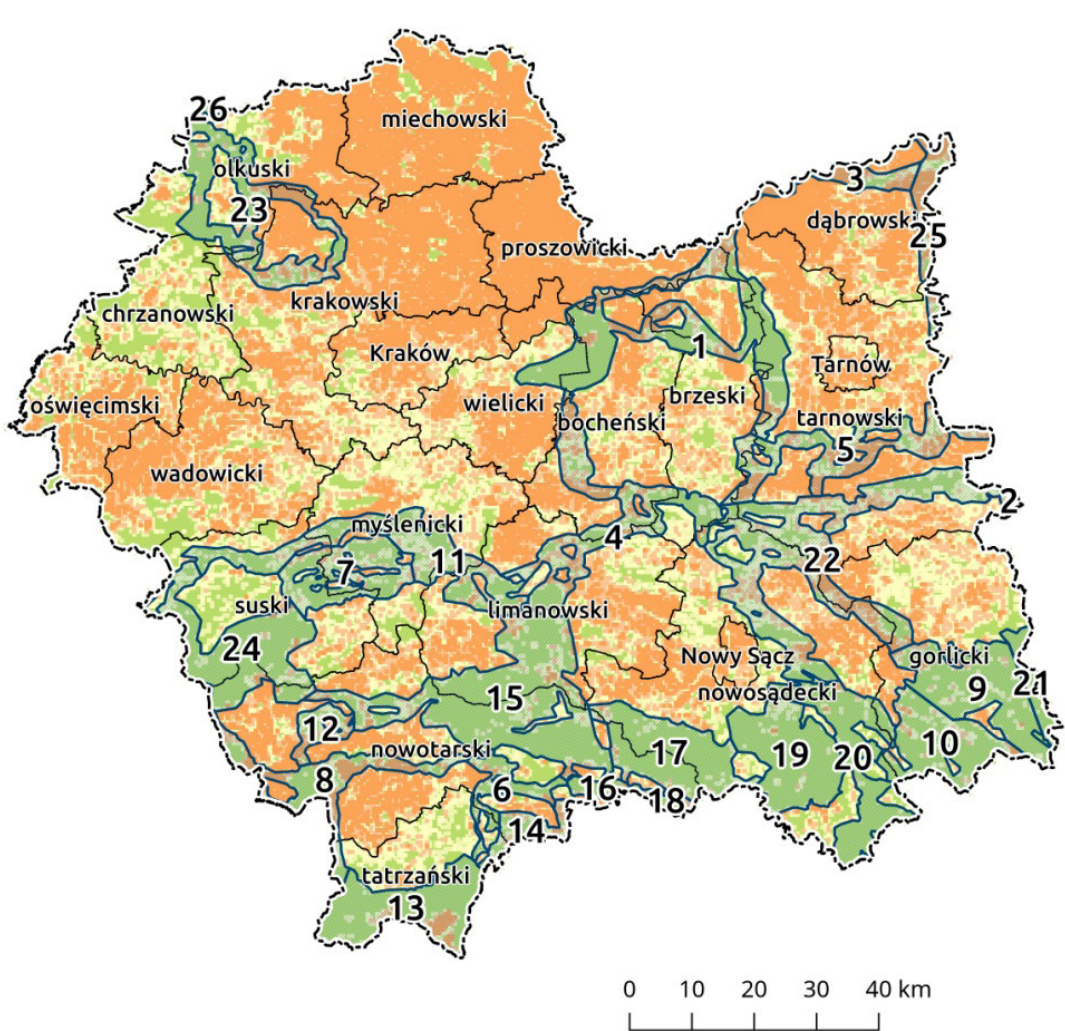

\section{KEY}

$\square$ ecological corridors
$\square$ districts borders
anthropogenic influence
parameter value for areas
mainly naturals
mostlynaturals
balance of naturals and anthropogenic
mostly anthropogenic
mainly anthropogenic

\begin{tabular}{|c|c|}
\hline ID & Corridor name \\
\hline 1 & Niepotomice forest \\
\hline 2 & Bieszczady-Gorce Mountains - east \\
\hline 3 & Nida River Valley \\
\hline 4 & Bieszczady-Gorce Mountains - west \\
\hline 5 & Bieszczady-Gorce Mountains - centre 2 \\
\hline 6 & Gorce-Pieniny Mountains \\
\hline 7 & Western Beskid Mountains 2 \\
\hline 8 & Orava-Nowy Targ Peatlands \\
\hline 9 & Beskid Mountains - east \\
\hline 10 & Beskid Mountains - centre 1 \\
\hline 11 & Western Beskid Mountains 1 \\
\hline 12 & Gorce Mountains - Orava-Nowy Targ Peatlands \\
\hline 13 & Tatra Mountains \\
\hline 14 & Pieniny-Tatra Mountains \\
\hline 15 & Gorce Mountains \\
\hline 16 & Pieniny Mountains \\
\hline 17 & Beskid Mountains - west \\
\hline 18 & Bieszczady-Pieniny Mountains \\
\hline 19 & Beskid Mountains - centre 3 \\
\hline 20 & Beskid Mountains - centre 2 \\
\hline 21 & Magura Refuge \\
\hline 22 & Bieszczady-Gorce Mountains - centre 1 \\
\hline 23 & Kraków-Częstochowa Upland \\
\hline 24 & Upper Vistula River - Babia Mountain \\
\hline 25 & Swiętokrzyskie Mountains and Vistula River \\
\hline 26 & Częstochowa east \\
\hline
\end{tabular}

Figure 5. Distribution of values of anthropogenic pressure functions 
case of high CAI value when the area has been strongly changed and used by people, the ecological corridor does not perform its function or realizes it insufficiently. It can cause exposure of natural human biocenosis to risks posed by men. Conversely, when CAI values are low - the area is especially valuable in terms of ecology as there was no human interference. Such lands should be particularly protected. However, surveys of such type need detailed analysis of human interference character and anthropogenic pressure on selected areas.

\section{CONCLUSIONS}

Changes of land coverage result from influence of both anthropogenic factors connected with human activity and natural ones on the environment. Land coverage described as physical state of land surface related to anthropopression is significantly connected with the way of its usage. Diverse ways of land coverage changes modelling can be found in literature where land coverage is mainly considered from the angle of four aspects: spatial, temporal, quantitive and analytical. By our anthropogenic activity, men constantly affect the environment being a witness of its transformations. Surrounding landscape becomes more and more heterogeneous which is confirmed by Szostak and Nowicka [2013].

With current tendencies in view, it is more and more important to research progressive in next years changes of land coverage and usage. It should also be noticed that elaborations which concern modelling of land coverage changes or the coverage analyses only are not made in a complex way that includes region's level in its range. Particular attention should be put to these studies which join advanced statistical methods with GIS techniques as this combination gives possibility to obtain complex and completely ,spatial" models that take chosen factors into account. Modern research techniques which use geo-informational systems become more important [Kozak 2003, Hladnik 2005, Jobin et al. 2003, Wężyk et al. 2013]. Thanks to them, it is possible to create maps and make them current as well as to perform comparative analyses both for individual areas and one research area over the years [Szostak, Nowicka 2013]. Increase of data that concern land coverage affected development of methods and analytical tools from that range which was confirmed by Kozak et al. [2014] in their surveys.
Used modification of the method of CAI anthropogenic pressure calculation provides a good way of spatial valorization of areas which are characterised by accurate spatial determining of the calculated parameter.

Using regulated size of the field of basic estimation, PPO enables proper calibration and accuracy of the tested elements' dynamics.

Using GIS spatial tools that have features of interoperability in spatial data access, processing and generation to such a kind of analyses creates opportunities to develop semi-automatic ways of assessment of environmental conditions in tested areas and permits constant development of usages, as in the case of problematic areas identification for ecological corridors.

\section{Acknowledgements}

The researches were financed from the subsidy granted by MSHE for statutory activities.

\section{REFERENCES}

1. Bank Danych Lokalnych. www.stat.gov.pl (access: 10.02.2016).

2. Corine Land Cover. 1996-2016. Inspekcja Ochrony Środowiska. http://clc.gios.gov.pl/ (access: 13.12.2015).

3. Degórski M. 2009. Krajobraz jako odbicie przyrodniczych i antropogenicznych procesów zachodzących w megasystemie środowiska geograficznego. Problemy Ekologii Krajobrazu, t. XXIII, 53-60.

4. Drzewiecki W. 2008. Monitoring zmian pokrycia i użytkowania terenu na podstawie wieloczasowych obrazów teledetekcyjnych. Roczniki Geomatyki. Tom VI. Zeszyt 3.

5. Dyrektywa 2007/2/WE Parlamentu Europejskiego Unii Europejskiej z dnia 14 marca 2007 ustanawiająca infrastrukturę informacji przestrzennej we Wspólnocie Europejskiej (INSPIRE).

6. Bičik I. et al. 2015. Land Use Changes in the Czech Republic 1845-2010. Socio-Economic Driving Forces, Springer Geography, Switzerland.

7. Generalna Dyrekcja Ochrony Środowiska. www.gdos.gov.pl (access: 15.03.2016).

8. Hladnik D. 2005. Spatial structure of disturbed landscapes in Slovenia. Ecological Engineering, Vol. 24, 17-27.

9. Jaworek J. 2012. Ocena historycznych cech krajobrazu jako podstawa dla ich ochrony w gospodarowaniu i planowaniu. Czasopismo Techniczne 
- Architektura, z. 29, 7-A/2012.

10. Jobin B., Beaulieu J., Grenier M., Belanger L., Maissoneuve C., Bordage D., Filion B. 2003. Landscape changes and ecological studies in agricultural regions, Quebec, Canada. Landscape Ecology. Vol. 18, 575-590.

11. Kistowski M. 2003. Przegląd wybranych podejść metodycznych w zakresie analizy oceny wpływu człowieka na środowisko przyrodnicze. Problemy Ekologii Krajobrazu, t. XVII, 60-61.

12. Kistowski M., Grzybowski P. 2013. Natężenie i redukcja obciążeń środowiska skutkami antropopresji w Polsce w latach 2000-2009 - studium przestrzenne w ujęciu gminnym. Inżynieria Ekologiczna, 34, 17-28.

13. Kozak J. 2003. Dokładność globalnych map użytkowania Ziemi i pokrycia terenu na przykładzie Global Land Cover Characterization Data Base. Archiwum Fotogrametrii, Kartografii i Teledetekcji, Vol. 13 A, 97-107.

14. Kozak J., Luc. M., Ostapowicz K., Ziółkowska E. 2014. Pozyskiwanie i analiza danych o pokryciu terenu a badania struktury przestrzennej krajobrazu. In: Ziaja W., Jodłowski M. (Eds) Struktura środowiska przyrodniczego a fizjonomia krajobrazu]. Instytut Geografii i Gospodarki Przestrzennej Uniwersytetu Jagiellońskiego, 63-84.

15. Krajewski P. 2010. Zmienność pokrycia terenu jako wskaźnik oceny przekształceń krajobrazu na przykładzie gminy Sobótka. In: Szumański M., Szulczewska B. (Eds) Horyzonty Architektury Krajobrazu - Przedmiot Architektury Krajobrazu, 56-62.

16. Krajewski P. 2011. Rozkład przestrzenny pokrycia terenu gminy Sobótka w kontekście oceny pojemności krajobrazu. Problemy Ekologii Krajobrazu, T. XXXI, 81-88.

17. Pietrzak M. 2015. Wybrane aspekty „terenowych” i „zdalnych” sposobów badania krajobrazu. Problemy Ekologii Krajobrazu. T. XXXIX, 139-142.

18. Pietrzak M. 2010. Podstawy i zastosowania ekologii krajobrazu - teoria i metodologia. Leszno.

19. Program Strategiczny Ochrona Środowiska.
2014. Załącznik do Uchwały Nr LVI/894/14 z dnia 27 października $2014 \mathrm{r}$. w sprawie zmiany Uchwały Nr XXXVI/443/05 Sejmiku Województwa Małopolskiego z dnia 29 sierpnia 2005 r. w sprawie „Programu Ochrony Środowiska Województwa Małopolskiego na lata 2007-2014".

20. Rozporządzenie Ministra Spraw Wewnętrznych i Administracji z dnia 17 listopada 2011 r. w sprawie bazy danych obiektów topograficznych oraz bazy danych obiektów ogólnogeograficznych, a także standardowych opracowań kartograficznych.

21. Soja R. 2002. Hydrologiczne aspekty antropopresji w polskich Karpatach. Polska Akademia Nauk. Instytut Geografii i Przestrzennego Zagospodarowania im. Stanisława Leszczyckiego. Prace Geograficzne, Nr 186.

22. Solon J. 2002. Ocena różnorodności krajobrazu na podstawie analizy struktury przestrzennej roślinności, Polska Akademia Nauk, Instytut Geografii i Przestrzennego Zagospodarowania im. S. Leszczyckiego, Prace Geograficzne, Nr 185.

23. Strategia Rozwoju Województwa Małopolskiego na lata 2011-2020. 2011. Załącznik Nr 1 do Uchwały Nr XII/183/11 Sejmiku Województwa Małopolskiego z dnia 26 września 2011 r.

24. Szostak M., Nowicka M. 2013. Zastosowanie technik geomatycznych w opracowywaniu map pokrycia i użytkowania terenu dla obszarów zrekultywowanych. Archiwum Fotogrametrii, Kartografii i Teledetekcji, Vol. 25.

25. Urząd Statystyczny w Krakowie. http://krakow. stat.gov.pl (access: 18.03.2016).

26. Urząd Statystyczny w Krakowie. 2016. Rocznik statystyczny województwa małopolskiego 2015, Kraków.

27. Ustawa $z$ dnia 4 marca 2010 r. o infrastrukturze informacji przestrzennej (Dz.U. $2010 \mathrm{nr} 76$ poz. 489).

28. Wężyk P., Wójtowicz-Nowakowska A., Pierzchalski M., Mlost J., Szafrańska B. 2013. Mapa zmian pokrycia terenu małopolski 1986-2011 wykonana w oparciu o klasyfikację obiektową obrazów satelitarnych LANDSAT oraz RapidEye. Archiwum Fotogrametrii, Kartografii i Teledetekcji, Vol. 25. 